\title{
EFFECT OF AGARICUS BISPORUS AND ORIGANUM MAJORANA L EXTRACT ON THE SHELF-LIFE AND NUTRITIONAL PROPERTIES OF PORK LIVER PÂTÉ
}

\author{
DORIN TIBULCA ${ }^{a}$, MELINDA FOGARAS ${ }^{a *}$, SONIA A. SOCACI ${ }^{b}$, \\ SZABOLCS FOGARASI ${ }^{c}$, CARMEN POP $^{\mathrm{b}}$, DAN SALAGEAN ${ }^{\mathrm{a}}$, \\ MARIA TOFANĂ ${ }^{b}$, DELIA MICHIU ${ }^{a}$
}

\begin{abstract}
The current study aimed to examine the effects of Agaricus bisporus and $O$. marjorana extract and their beneficial impact on the shelflife and nutritional changes occurring in pork liver pâté during storage time. Based on the obtained result, regarding the characterization of $O$. marjorana essential oil (OMEO) and mushroom powder, three types of pork liver pâté were formulated with different proportion of OMEO and mushroom powder and they were sensory evaluated using the 9-point hedonic test. In order to determine the stability during storage time, the selected sample and the control sample were sampled initially, after $30,60,90$ and 120 days of storage than subjected to physicochemical (protein, fat, moisture, ash, total carbohydrates, and energy) evaluation.
\end{abstract}

Keywords: Agaricus bisporus, biochemical changes, essential oil, Origanum majorana L., pork liver pâté, sensory evaluation, volatile profile

\section{INTRODUCTION}

The partial replacement of animal fat by plant extracts is one of the most effective strategies to reduce the saturated fatty acid content of meat products, which has gained importance due to the consumer's concern about

a Department of Food Engineering, University of Agricultural Sciences and Veterinary edicine of Cluj-Napoca, Cluj-Napoca, Romania, Calea Mănăştur 3-5, 400372 Cluj-Napoca, Romania

${ }^{\mathrm{b}}$ Department of Food Science, University of Agricultural Sciences and Veterinary Medicine of Cluj-Napoca, Cluj-Napoca, Romania, Calea Mănăştur 3-5, 400372 Cluj-Napoca, Romania

c Babeş-Bolyai University, Faculty of Chemistry and Chemical Engineering, Department of Chemical Engineering 11 Arany Janos Str., Cluj-Napoca, RO-400028, Romania

*Corresponding author: melinda.fogarasi@usamvcluj.ro 
the harmful effects of saturated fat [1]. Currently, many consumers demand low-fat foods with healthy ingredients. Some vegetable oils and vegetables are the important source of poly unsaturated faty acids (PUFAs) as well as minor components such as phytosterols and tocopherols. They have been employed as saturated fat replacers in meat products. However, the reduction and substitution of lipids can affect the physicochemical characteristics of high fat foods like sausages, burgers and pâté [2]

Liver pâté is a traditional food manufactured using liver from pig, byproducts of pork and other characteristic ingredients. It is consumed all over the world, especially in European countries and is generally considered an added value product with high nutritional and sensory qualities. On the other hand, liver pâté is considered as a high-caloric food product with large amounts of saturated fats. The contribution of this type of fat to the development of cardiovascular diseases, cancer, diabetes and other degenerative diseases, has led to meat industry to seek strategies to reformulate these products with increasing levels of PUFA. A good option could be the replacement of animal fat with vegetable one rich in unsaturated fatty acids [3].

A. bisporus is an edible species that is extensively cultivated throughout Europe and an appreciated nutritional source for humans' diet due to their low caloric intake and their high content in proteins, dietary fibre and phenolic compounds [4]. From the functional perspective, mushrooms are low in fat and cholesterol. The bioactivity exhibited by these compounds is also linked with the presence of phenolic compounds, polyketides, terpenes, steroids, $\beta$ carotene, and some vitamins, such as $A$ and $C$, all of them related with antimicrobial, antiviral, antioxidant or anti-inflammatory activities [5].

A great diversity of species of plants has gained the attention of the food industry as food preservatives. These plants are made up of bioactive compounds that act to protect plants from microbiological attacks, but they have also been exploited and employed by humans as food and medicinal sources for thousands of years. O. marjorana essential oil is a unique cooking additive with many additional internal and external benefits. $O$. majorana essential oil possesses antioxidant, antimicrobial, cytotoxic and acetycholinesterase properties, thus providing strong support for their promising candidacy for use as natural agents in various applications, including food preservation, cosmetic preparations, medical or therapeutic products. It also has a positive effect on the nervous system.

Therefore, the aim of this study was to evaluate the effect of Agaricus bisporus powder and the essential oil extracts of $O$. majorana on pork liver pâtés by evaluating the physico-chemical and sensory characteristics of the product during the storage time. 


\section{RESULTS AND DISCUSSION}

\section{Chemical composition of Agaricus bisporus}

We studied the chemical composition of the Agaricus bisporus cultivated mushroom, which are most popular and regularly consumed by the population in Romania. The results concerning the nutritional value of the selected mushroom are presented in Table 1 . Carbohydrates $(55,85 \%)$ were the major constituents, followed by proteins $(26,42 \%)$ and ash (8,63\%). Fat contents were low what is understandable because many studies reveal that A. bisporus are regarded as an important dietary supplement for people interested in calorie restriction $[4,6]$. The result for this specie is in agreement with the literature [7], and it gave the lowest content in fat, but the highest energetic contribution, due to the highest protein levels. The total fat, protein and ash values obtained for $A$. bisporus in this work, is also in agreement with the values reported by Kalac et al. [8]. Nevertheless, the total fat found in our cultivated mushroom is lower than the values reported for wild edible mushroom in the same species [4]. On the other hand, the protein content in wild edible Agaricus bisporus is more higher than in cultivated Agaricus bisporus. These differences may be attributed to a number of factors that can influence the mushrooms protein contents, namely the type of mushroom, the stage of development, the part sampled, level of nitrogen available and the harvest location.

Table 1. Nutrition value of Agaricus bisporus mushroom

\begin{tabular}{|l|l|}
\hline & Agaricus bisporus \\
\hline Fat $\mathbf{( g / 1 0 0 ~} \mathbf{~ g})$ & $1,98 \pm 0,08$ \\
\hline Protein $\mathbf{g} / \mathbf{1 0 0} \mathbf{~ g})$ & $26,42 \pm 0,12$ \\
\hline Moisture $\mathbf{( g / 1 0 0 ~} \mathbf{g})$ & $7,12 \pm 0,20$ \\
\hline Ash $\mathbf{( g / 1 0 0 ~ g ) ~}$ & $8,63 \pm 0,06$ \\
\hline $\begin{array}{l}\text { Total carbohydrates } \\
\text { (g/100 g) }\end{array}$ & $55,85 \pm 0,10$ \\
\hline Energy (kcal/100 g) & $346,9 \pm 0,14$ \\
\hline
\end{tabular}

\section{Chemical composition of essential oil}

The volatile compounds detected by ITEX-GC/MS analysis of the O. marjorana essential oil with their percentage composition are summarized in Table 2. 
DORIN TIBULCA, MELINDA FOGARASI, SONIA A. SOCACI, SZABOLCS FOGARASI, CARMEN POP, DAN SALAGEAN, MARIA TOFANĂ, DELIA MICHIU

Table 2. Volatile compounds profile of $O$. majorana essential oil

\begin{tabular}{|c|c|}
\hline Compounds & $\begin{array}{c}\text { OMEO } \\
\text { Conc. (\%, of total peaks area) }\end{array}$ \\
\hline$\alpha$-Thujene & 0,56 \\
\hline 4(10)-Thujene & 0,69 \\
\hline a-Pinene & 6,7 \\
\hline$\beta$-Pinene & 0,4 \\
\hline$\beta$-Myrcene & 1,44 \\
\hline a-Phellandrene & 0,36 \\
\hline$\alpha$-Terpinene & 7,12 \\
\hline$p$-Cymene & 2,9 \\
\hline D-Limonene & 1,62 \\
\hline$\beta$-Phellandrene & 1,64 \\
\hline Eucalyptol & 0,2 \\
\hline $\mathrm{Y}$-Terpinene & 12,03 \\
\hline n.i. & 3,97 \\
\hline Terpinolene & 2,81 \\
\hline $\begin{array}{l}\text { Bicyclo[3.1.0]hexan-2-ol, 2-methyl-5-(1- } \\
\text { methylethyl)-, (1.alpha.,2.alpha.,5.alpha.)- }\end{array}$ & 15,06 \\
\hline n.i. & 1,63 \\
\hline n.i. & 1,02 \\
\hline 1-Terpinen-4-ol & 27,97 \\
\hline a-Terpineol & 4,4 \\
\hline n.i. & 0,05 \\
\hline $\begin{array}{l}\text { 2-Cyclohexen-1-ol, 3-methyl-6-(1-methylethyl)-, } \\
\text { trans- }\end{array}$ & 0,5 \\
\hline Carvone & 0,06 \\
\hline Linalool acetate & 2,25 \\
\hline n.i. & 0,11 \\
\hline 1-Terpinen-4-ol acetate & 0,2 \\
\hline Caryophyllene & 2,74 \\
\hline a-Caryophyllene & 0,07 \\
\hline n.i. & 1,27 \\
\hline n.i. & 0,17 \\
\hline
\end{tabular}

OMEO- O. majorana essential oil n.i. - not identified

The results from the GC-MS analysis of the volatile EO constituents revealed the presence of a total of 29 components, their abundance being expressed as percentage of total peaks area. The most abundant constituents were 1-terpinen-4-ol $(27,97 \%)$ followed by bicyclo[3.1.0]hexan-2-ol,2-methyl5-(1-methylethyl)-,(1.alpha.,2.alpha.,5.alpha.) (15,06\%) y-terpinene (12,03\%), 
a-terpinene (7,12\%) and a-pinene (6,7\%). 1-Terpinen-4-ol is a characteristic volatile constituent of marjoram leaves that contribute to the fruity, floral, terpenous aroma. These results are in accordance with previous studies reported by Hajlaoui $\mathrm{H}$. that also found 1-terpinen-4-ol $(23,2 \%)$, and $\mathrm{\gamma}$-terpinene $(10.5 \%)$ as the major components of O. majorana EO [9].

\section{Antibacterial activity of 0 . majorana essential oil}

In order to evaluate the antibacterial activity, minimum inhibitory concentration tests of the studied essential oil were performed. According to the results shown in Table 3, minimum inhibitory concentrations values differ significantly.

Table 3. Minimum inhibitory concentrations (MIC) of OMEO

\begin{tabular}{|c|c|c|c|c|}
\hline \multirow{2}{*}{ Essential Oil } & $\begin{array}{c}\text { E. coli } \\
\text { ATCC } \\
25922\end{array}$ & $\begin{array}{c}\text { S. aureus } \\
\text { ATCC 25923 }\end{array}$ & $\begin{array}{c}\text { S. enteritidis } \\
\text { ATCC 13076 }\end{array}$ & $\begin{array}{c}\text { L. } \\
\text { monocytogenes } \\
\text { ATCC 19114 }\end{array}$ \\
\cline { 2 - 5 } & \multicolumn{4}{|c|}{$\mu \mathrm{l} / \mathrm{ml}$} \\
\hline OMEO & $2.45 \pm 0,00$ & $5.14 \pm 0,00$ & $5.14 \pm 0,00$ & $10.80 \pm 0,00$ \\
\hline Gentamicin & $0.05 \pm 0,00$ & $0.05 \pm 0,00$ & $0.11 \pm 0,00$ & $0.11 \pm 0,00$ \\
\hline
\end{tabular}

The results show that $O$. marjorana has the most bacteriostatic effect against all four of the selected bacteria, considering that it displayed the lowest MIC values. In the case of bacteria $S$. aureus and S. enteritidis had the same antibacterial activity $(5.14 \mu \mathrm{l} / \mathrm{ml})$. The antibacterial activity of $O$. marjorana was also the most bacteriostatic against $\mathrm{E}$. coli, followed by $\mathrm{S}$. aureus, $\mathrm{S}$. enteritidis and L. monocytogenes. These findings are in agreement with the data reported in the literature regarding the MIC values of $O$. marjorana $[9,10]$.

\section{Sensorial analysis}

Sensory science has been recognized as a scientific discipline, and sensory evaluation of meat is used as a component of meat quality, shelf life, and consumer-acceptance studies. It has long been recognized that the sensory attributes of meat are important for consumer acceptability, and by understanding these relationships, the meat industry can improve or decrease variability in specific meat sensory properties and increase consumer satisfaction. The Hedonic testing was used to determine consumer's attitude towards all three liver pâté samples by measuring the degree of acceptance of the new 
products. It is very important to note that the organoleptic properties of liver pâté enhanced with mushroom powder and essential oil remained acceptable to consumers and the quality level similar to the current commercially available products. This is also confirmed by the results shown in the Table 4 for sensorial evaluation of liver pâté samples containing different level of mushroom powder and essential oil compared to the control sample (without EOs).

Table 4. Results of sensorial evaluation

\begin{tabular}{|l|c|c|c|c|c|c|}
\hline \multicolumn{1}{|c|}{ Sample } & Appearance & Color & Texture & Odor & Taste & $\begin{array}{c}\text { Overall } \\
\text { acceptability }\end{array}$ \\
\hline C.S. & 7 & 8,2 & 8,5 & 6,4 & 7,2 & 7,4 \\
\hline M1OMEO & 7,2 & 8,5 & 8 & 7,4 & 7 & 7,6 \\
\hline M2OMEO & 8,5 & 8,4 & 8,7 & 8 & 8,5 & 8,4 \\
\hline
\end{tabular}

C.S. - control sample, M1OMEO - 15\% mushroom powder and 0,02\% OMEO and M2OMEO - $25 \%$ mushroom powder and 0,01\% OMEO

The enriched liver pâté showed significant differences for sensory descriptors compared to the control sample. Moreover, the enriched liver pâtés were characterized by more intense color, odor and taste as the concentration of mushroom power increased.

The O. majorana essential oil has given a fresh taste and smell to the product and it reduces the fatty taste of the product. Moreover, the liver pâté with $25 \%$ mushroom powder and 0,01\% OMEO reached the highest hedonic score, having a mean sensory score for the visual appearance color, odor and taste of $8.4,8$ and 8.5 respectively, as showed in the Table 4.

\section{The physicochemical evaluation of the liver pâté}

The results of the proximate composition presented in Table 5 shows the moisture, lipid, protein, ash, carbohydrates and energy values of pork liver pâté samples with and without mushroom powder and O. marjorana essential oil in glass containers stored under refrigeration.

In this study the analyzed samples proximate composition showed significant difference between two samples considering that M2OMEO pork liver pâté sample had higher protein and lower lipids content. These differences may be attributed to the replaced of pork subcutaneous fat with mushroom powder. 
EFFECT OF AGARICUS BISPORUS AND ORIGANUM MAJORANA L EXTRACT ON THE SHELFLIFE AND NUTRITIONAL PROPERTIES OF PORK LIVER PÂTÉ

Table 5. The compositional parameters percentage values according to the storage time

\begin{tabular}{|c|c|c|c|c|c|c|c|}
\hline Sample & $\begin{array}{c}\text { Storage } \\
\text { time }\end{array}$ & Fat (\%) & Protein (\%) & \begin{tabular}{|c} 
Moisture \\
(\%)
\end{tabular} & Ash (\%) & $\begin{array}{c}\text { Carbohyd- } \\
\text { rates (\%) }\end{array}$ & $\begin{array}{c}\text { Energy } \\
\text { (kcal) }\end{array}$ \\
\hline \multirow{5}{*}{ C.S. } & $\begin{array}{l}\text { initial } \\
\text { state }\end{array}$ & $22,15 \pm 0,02$ & $12,59 \pm 0,12$ & $58,24 \pm 0,24$ & $3,41 \pm 0,11$ & $3,61 \pm 0,26$ & $264,15 \pm 0,17$ \\
\hline & 30 days & $22,18 \pm 0,16$ & $12,62 \pm 0,41$ & $58,2 \pm 0,25$ & $3,42 \pm 0,08$ & $3,58 \pm 0,10$ & $264,42 \pm 0,15$ \\
\hline & 60 days & $22,21 \pm 0,14$ & $12,53 \pm 0,08$ & $58,27 \pm 0,27$ & $3,42 \pm 0,35$ & $3,57 \pm 0,21$ & $264,29 \pm 0,22$ \\
\hline & 90 days & $22,31 \pm 0,01$ & $12,49 \pm 0,10$ & $58,32 \pm 0,31$ & $3,43 \pm 0,57$ & $3,45 \pm 0,40$ & $264,55 \pm 0,11$ \\
\hline & 120 days & $22,39 \pm 0,06$ & $12,43 \pm 0,36$ & $58,39 \pm 0,32$ & $3,43 \pm 0,05$ & $3,36 \pm 0,18$ & $264,67 \pm 0,50$ \\
\hline \multirow{5}{*}{ M2OMEO } & $\begin{array}{l}\text { initial } \\
\text { state }\end{array}$ & $17,41 \pm 0,04$ & $21,18 \pm 0,48$ & $53,80 \pm 0,26$ & $3,50 \pm 0,20$ & $4,11 \pm 0,20$ & $257,85 \pm 0,05$ \\
\hline & 30 days & $17,45 \pm 0,12$ & $21,22 \pm 0,51$ & $53,75 \pm 0,32$ & $3,5 \pm 0,24$ & $4,08 \pm 0,10$ & $258,25 \pm 0,42$ \\
\hline & 60 days & $17,48 \pm 0,24$ & $21,25 \pm 0,54$ & $53,71 \pm 0,37$ & $3,51 \pm 0,11$ & $4,05 \pm 0,47$ & $258,52 \pm 0,28$ \\
\hline & 90 days & $17,51 \pm 0,31$ & $21,29 \pm 0,22$ & $53,68 \pm 0,13$ & $3,52 \pm 0,10$ & $4,00 \pm 0,18$ & $258,75 \pm 0,25$ \\
\hline & 120 days & $17,56 \pm 0,04$ & $21,34 \pm 0,47$ & $53,64 \pm 0,30$ & $3,52 \pm 0,01$ & $3,94 \pm 0,24$ & $259,16 \pm 0,10$ \\
\hline
\end{tabular}

The use of cold storage had a significant effect on the lipid and protein content, since the lipid and protein content gradually increased with storage time. This increase can be attributed to the reduction of moisture content with storage time. In contrast, the fluctuations in composition in the case of the controil sample can be attributed to protein oxidation. Regarding the packing, Amaral et al. analysed lamb pâté during repining [11] and reported that the polyamide casing system showed lower values of moisture, indicating a greater permeability when compared with glass packing, differing statistically only in the first 15 days of storage. Similar behavior was observed by Amaral et al., the only difference being that they used raw material from another species of animal (sheep, goat) [11, 12].

\section{CONCLUSIONS}

The obtained original results proved that Agaricus bisporus and Origanum majorana $I$. extract can improve the shelf-life and nutritional properties of pork liver pâté, leading to viable alternative to add value to pork 'variety meat', as well as providing greater profitability. It was found, that the 
stability of the product is due to the antimicrobial activity of the OMEO which has not only bacteriostatic effect but contributes to the attractive texture, taste and color of the product together with Agaricus bisporus. As an overall conclusion it can be stated that the liver pâté with $25 \%$ mushroom powder and $0,01 \%$ OMEO is the best option considering that it reached the highest hedonic score, showed good physicochemical characteristics and did not indicate a possible protein and lipid oxidation, thus did not affect the protein content throughout the storage period.

\section{EXPERIMENTAL SECTION}

\section{Plant Materials and Essential Oils Extraction}

The selected mushroom specie (Agaricus bisporus) was purchased from a local producer and the dried marjoram leaves were procured from a company that markets food ingredients (Solina Group, Alba lulia, Romania). Fresh and cleaned mushrooms were randomly divided and dried using a laboratory plant dryer at $45{ }^{\circ} \mathrm{C}$ until reaching a constant mass. Afterwards, the mushroom material was ground into a fine powder using a laboratory mill, mixed to obtain a homogeneous sample, and kept at $4{ }^{\circ} \mathrm{C}$, for further analyses. O.Marjorana essential oil (OMEO) was obtained by hydrodistillation using 50 $\mathrm{g}$ dried leaves. The extraction was performed for $3 \mathrm{~h}$ with $750 \mathrm{~mL}$ distilled water in a Clevenger-type apparatus (S.C. Energo-Metr S.R.L., Odorheiu Secuiesc, Romania). The essential oils were dried over anhydrous sodium sulphate and stored at $4^{\circ} \mathrm{C}$ until analysis.

\section{Nutrition value of Agaricus bisporus}

The chemical composition of Agaricus bisporus mushroom, including moisture, ash, total carbohydrates, total energy, crude fat and crude protein, were determined according to AOAC procedures[4]. To obtain the moisture content, sample of the mushroom were dried at $105^{\circ} \mathrm{C}$ until constant weight. The ash content was determined by incineration at $600 \pm 15^{\circ} \mathrm{C}$ for $6 \mathrm{~h}$. The crude protein content of the samples was estimated by the Kjeldahl method. For the calculation of crude protein in mushroom, the nitrogen content was multiplied by a factor of 4.38 [13]. The crude fat content of the samples was determined by extracting a know weight of powdered mushroom sample ( $3 \mathrm{~g}$ ) with petroleum ether as a solvent, using Soxhlet apparatus [14]. The amount of total carbohydrate was calculated by difference [15]: 100 - ( $\mathrm{g}$ moisture $+\mathrm{g}$ protein $+g$ fat $+g$ ash). The total energy was calculated according to the following equations [15]: energy $(\mathrm{kcal})=4 \times(\mathrm{g}$ protein $+\mathrm{g}$ carbohydrate $)+9$ $\times$ (g lipid) 


\section{ITEX/GC-MS Analysis of Volatile Components}

The extraction of volatile oil performed by hydrodistillation using a Clevenger type apparatus according to Socaci et al., 2008 [16]. The extracted essential oil was collected and $1 \mu \mathrm{L}$ of essential oil solution was used for analysis of volatile compounds on a GCMS QP-2010 (Shimadzu Scientific Instruments, Kyoto, Japan) model gas chromatograph-mass spectrometer. The volatile constituents were separated on a Zebron ZB- $5 \mathrm{~ms}$ capillary column of $30 \mathrm{~m} \times 0.25 \mathrm{~mm}$ i.d. $\times 0.25 \mu \mathrm{m}$ film thickness. In all determinations, the carrier gas was $\mathrm{He}, 1 \mathrm{ml} / \mathrm{min}$ and the split ratio 1:100. The temperature program used for the column oven was: from $50{ }^{\circ} \mathrm{C}$ (kept at this temperature for $2 \mathrm{~min}$ ) to $160{ }^{\circ} \mathrm{C}$ at $4{ }^{\circ} \mathrm{C} / \mathrm{min}$, then raised to $250{ }^{\circ} \mathrm{C}$ at $15{ }^{\circ} \mathrm{C} / \mathrm{min}$ (kept at this temperature for 10 min). The injector, ion source and interface temperatures were set at $250{ }^{\circ} \mathrm{C}$ and the MS mode was electron impact $(\mathrm{EI})$ at ionization energy of $70 \mathrm{eV}$. The scanned mass range was $40-500 \mathrm{~m} / \mathrm{z}$. Volatile compounds were tentatively identified using the spectra of reference compounds from NIST27 and NIST147 mass spectra libraries and verified by comparison with retention indices drawn from www.pherobase.com or www.flavornet.org (for columns with a similar stationary phase to the ZB-5ms column). Compounds were considered "tentatively identified" only in the case in which their mass spectra similarity value was above $85 \%$. All peaks found in at least two of the three total ion chromatograms (TIC) were considered when calculating the total area of peaks (100\%) and the relative areas of the volatile compounds.

\section{Bacterial Strains}

The antimicrobial activity of $O$. marjorana essential oil was determined using the methods presented in the scientific literature [17].The following microorganisms were tested: Escherichia coli (ATCC 25922), Staphylococcus aureus (ATCC 25923), Salmonella enteritidis (ATCC 13076) and Listeria monocytogenes (ATCC 19114). All strains were grown into a test tube containing $10 \mathrm{~mL}$ sterile nutrient broth (Oxoid Ltd., Basingstoke, Hampshire, England) at $37{ }^{\circ} \mathrm{C}$ for $24 \mathrm{~h}$ in the case of E. coli, S. aureus and S. enteritidis, while L. monocytogenes at $37 \circ \mathrm{C}$ for $30 \mathrm{~h}$. The purity of the inoculums was confirmed by plating on appropriate selective media and microscopic examination of the Gram-stained smear (Optika microscope, B-252, M.A.D. Apparecchiature Scientifiche, Milan, Italy). A loopful of inoculums was transferred by streaking onto a selective medium: TBX for E. coli, BP (baird parker) for S. aureus, XLD agar (Oxoid Ltd., Basingstoke, Hampshire, England) for S. enteritidis and Palcam agar base (Oxoid Ltd., Basingstoke, Hampshire, England) with added Palcam selective supplement for L. monocytogenes. Plates were incubated at $44{ }^{\circ} \mathrm{C}$ for $24 \mathrm{~h} \mathrm{E}$. coli, at $37^{\circ} \mathrm{C}$ for $24 \mathrm{~h}$ in the case of S. Aureus, and 
S. enteritidis and at $37{ }^{\circ} \mathrm{C}$ for $30 \mathrm{~h}$ in the case of L. monocytogenes. Bacterial morphology was confirmed by optical microscopy. Several colonies were collected with a sterile inoculating loop, transferred into sterile saline solution $\left(8.5 \mathrm{~g} \mathrm{~L}^{-1}\right)$, and adjusted to match the turbidity of a McFarland 0.5 standard $\left(1.5 \times 108 \mathrm{CFUmL}^{-1}\right)$ [31]. Then, three serial 10 -fold dilutions $(107,106$, and

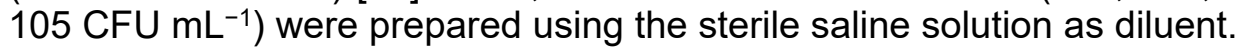

\section{Manufacture of the pâtés}

All pork liver pâtés samples were elaborated in the Experimental Laboratory of Meat Products (pilot scale) of the Faculty of Food Science and Technology, Cluj-Napoca (University of Agricultural Sciences and Veterinary Medicine Cluj-Napoca, Romania). Three batches of liver pâté were prepared by replacing pork with mushroom powder: CS (control sample without addition of mushroom powder and OMEO), M1OMEO (with 15\% mushroom powder and 0,02\% oMEO) and M2OMEO (with $25 \%$ mushroom powder and $0,01 \%$ OMEO). An identical formula was used for all the batches, except for the addition of the different antioxidants. The recipes (\%) used for the preparation of the control sample were as follows: pork subcutaneous fat $(52,5 \%)$, broth (the boiling water in which the fat was cooked) $(7 \%)$, liver $(35 \%)$, sodium chloride $(1,4 \%)$, nutmag $(0,01 \%)$, pepper $(0,07 \%)$, onion $(3 \%)$, sugar $(1 \%)$ and paprika $(0,02 \%)$. During the manufacturing process the pork subcutaneous fat and liver were cut into cubes of about $15 \mathrm{~mm}$ side and scalding at $65^{\circ} \mathrm{C}$ for $60 \mathrm{~min}$. The cooked liver and subcutaneous fat was mixed in the cutter with the other ingredients until a homogeneous raw batter was obtained. For the M1OMEO and M2OMEO samples the corresponding ingredients were added. Finally, the batter was manually distributed into glass flasks until completely full $(250 \mathrm{~g})$ and these were then hermetically closed which were subjected to a heat treatment in a stainless steel autoclave. In the core of the pâtés, temperature remained constant at $80 \pm$ $2^{\circ} \mathrm{C}$ for 30 min being monitored with a Cu-Constantan type $\mathrm{T}$ thermocouple. Subsequently, the flasks were cooled to room temperature and stored in the dark at $4 \pm 1{ }^{\circ} \mathrm{C}$ for 120 days.

\section{Sensory evaluation of liver pâté}

Sensory characteristics of pork liver pâté samples were evaluated by a panel of 50 untrained assessors, with a mean age of 20-40, consisted of students and staff members of the department. All samples were coded numerically and supplied in plastic dishes randomly. The 9-point hedonic scale test ( 1 being "dislike extremely" and 9 being "like extremely") was used to evaluate all liver pâté samples. The main sensory attributes used in the assessment of the samples were appearance, color, texture, odor, taste, and overall acceptability. 


\section{Physicochemical parameters of pork liver pâté samples}

Protein, fat, and moisture content were analysed using the Food ScanTM Lab 78810 (Foss Tecator Co., Ltd., Denmark). Three replicates were run for each sample. The results were expressed as $\mathrm{g} / 100 \mathrm{~g}$ sample. The liver pâté samples samples ash content was established by incineration at $600 \pm 15{ }^{\circ} \mathrm{C}$. The amount of total carbohydrate resulted as a difference based on the following equation: $100-$ ( $g$ moisture $+g$ protein $+g$ fat $+g$ ash) [15]. The total energy was calculated using the following equation from the literature: energy $(\mathrm{kcal})=4 \times(\mathrm{g}$ protein $+\mathrm{g}$ carbohydrate $)+9 \times(\mathrm{g}$ lipid $)[15]$.

\section{ACKNOWLEDGEMENTS}

This work was supported by two grants of Ministry of Research and Innovation, CNCS-UEFISCDI, project number PN-III-P1-1.1-TE-2016-0973 and project number PN-III-P2-2.1-Cl-2018-1355.

\section{REFERENCES}

1. R.T. Heck, B.N. Lucas, D. Santos, M.B. Pinton, M.B. Fagundes, M. de Araujo Etchepare, A.J. Cichoski, C.R. de Menezes, J.S. Barin, R. Wagner, P.C.B. Campagnol, Meat Sci, 2018, 146, 147-153.

2. A.M. Terrasa, M. Dello Staffolo, M.C. Tomás, LWT - Food Sci and Tech, 2016, 66, 678-684.

3. R. Agregan, D. Franco, J. Carballo, I. Tomasevic, F.J. Barba, B. Gomez, V. Muchenje, J.M. Lorenzo, Food Res Int, 2018, 112, 400-411.

4. M. Fogarasi, S.A. Socaci, F.V. Dulf, Z.M. Diaconeasa, A.C. Farcas, M. Tofana, C.A. Semeniuc, Molecules, 2018, 23, 12,

5. M. Ramos, N. Burgos, A. Barnard, G. Evans, J. Preece, M. Graz, A.C. Ruthes, A. Jimenez-Quero, A. Martinez-Abad, F. Vilaplana, L.P. Ngoc, A. Brouwer, B. van der Burg, M. Del Carmen Garrigos, A. Jimenez, Food Chem, 2019, 292, 176-187.

6. M. Nagy, S. Socaci, M. Tofana, E.S. Biris-Dorhoi, D. ȚlbulcĂ, G. PetruȚ, C.L. Salanta, Bulletin USAMV. Food Sci and Tech, 2017, 74, 1, 1.

7. N. CHERNO, S. OSOLINA, A. NIKITINA, Food and Envi Saf journal, 2013, XII,, 4, $291-299$.

8. P. Kalač, Food Chemistry, 2009, 113, 1, 9-16. 
DORIN TIBULCA, MELINDA FOGARASI, SONIA A. SOCACI, SZABOLCS FOGARASI, CARMEN POP, DAN SALAGEAN, MARIA TOFANĂ, DELIA MICHIU

9. H. Hajlaoui, H. Mighri, M. Aouni, N. Gharsallah, A. Kadri, Microbial pathogenesis, 2016, 95, 86-94.

10. J.d.L. Marques, L.M. Volcão, G.D. Funck, I.S. Kroning, W.P. da Silva, Â.M. Fiorentini, G.A. Ribeiro, Industrial Crops and Products, 2015, 77, 444-450.

11. D.S. Amaral, F.A.P. Silva, T.K.A. Bezerra, N.M.O. Arcanjo, I.C.D. Guerra, P.S. Dalmás, M.S. Madruga, Food Pack and Shelf Life, 2015, 3, 39-46.

12. D. Amaral, F.A.P.d. Silva, T.K.A. Bezerra, I.C.D. Guerra, P.S. Dalmás, K.M.L. Pimentel, M.S. Madruga, Semina: Ciências Agrárias, 2013, 34, 4,

13. A. Mocan, A. Fernandes, L. Barros, G. Crisan, M. Smiljkovic, M. Sokovic, I. Ferreira, Food \& function, 2018, 9, 1, 160-170.

14. M. Nagy, C. Mureşan, S.A. Socaci, M. Tofană, A. Fărcaș, S.E. Biriş, Bulletin USAMV Food Sci and Tech, 2015, 72, 2,

15. M. Obodai, I.C. Ferreira, A. Fernandes, L. Barros, D.L. Mensah, M. Dzomeku, A.F. Urben, J. Prempeh, R.K. Takli, Molecules, 2014, 19, 12, $19532-19548$.

16. Sonia A. Socaci, Maria Tofană, C. Socaciu, Bulletin UASVM, Agriculture, 2008, 65,2 ,

17. M. Fogarasi, S.A. Socaci, S. Fogarasi, M. Jimborean, C. Pop, M. Tofană, A. Rotar, D. Tibulca, D. Salagean, L. Salanta, Studia UBB Chemia, 2019, 64, 2 T2, 527537. 